\title{
Detection of early protein-calorie malnutrition (pre-kwashiorkor) in population groups
}

\author{
By H. A. PRASANNA, B. L. M. DESAI AND M. NARAYANA RAO \\ Discipline of Applied Nutrition and Dietetics, \\ Central Food Technological Research Institute, Mysore, India
}

(Received 20 fuly 1970-Accepted 31 December 1970)

\begin{abstract}
I. The heights and weights and the serum total protein concentration and ratio of nonessential to essential amino acids (NEA:EA ratio) were determined in twenty-six Indian children, aged from ${ }^{\prime} \cdot 5$ to 5 years, suffering from early protein-calorie malnutrition (prekwashiorkor children).

2. The heights and weights of the majority of the children approximated to $75-85 \%$ of the values for normal Indian children. The serum NEA:EA ratio of the children varied from 2.5 to $4^{\circ} \circ$. There was no correlation between this ratio and weight deficit. In healthy children of the same socio-economic group, the serum NEA:EA ratio varied from $I \cdot 5$ to $2 \cdot 1$ with a mean of $1 \cdot 7$. The results show that the NEA:EA ratio may be useful as an index for the detection of pre-kwashiorkor conditions.

3. There was a significant $(P<0.05)$ negative correlation $(r=-0.45)$ between serum albumin and NEA:EA ratio of the children. All the children showed consistently a significant increase in serum $\gamma$-globulin.
\end{abstract}

The widespread prevalence and great public health significance of protein-calorie malnutrition among young children in most technically underdeveloped nations of the world is now well recognized. The vitality and development of these nations depend largely on the way in which they challenge the extension of malnutrition in their populations.

Despite recent progress, no one single criterion permits the detection of prekwashiorkor or early protein-calorie malnutrition in population groups. The criteria for the diagnosis of this condition by clinical examination are difficult to define with precision. Whitehead ( 1964 ) has advocated the value of the ratio of non-essential to essential amino acids (NEA:EA ratio) in blood plasma for the detection of proteincalorie malnutrition, and especially of kwashiorkor, in population groups. McLaren, Kamel \& Ayyoub (r 965), Anasuya \& Narasinga Rao (r968) and Truswell, Wannenburg, Wittmann \& Hansen (I966) have expressed certain reservations on the validity of this approach.

The study now described was carried out essentially to find out the usefulness of the ratio of serum non-essential to essential amino acids in the detection of early protein-calorie malnutrition.

\section{EXPERIMENTAL}

\section{Subjects}

Children coming for medical check-up were screened at the paediatric out-patient clinic and those showing early, mild and advanced symptoms of protein malnutrition were referred to the nutrition clinic. Children who failed to grow but showed none 
of the other accepted signs of kwashiorkor in more than a slight degree were considered as suffering from early protein-calorie malnutrition. In these children, who were the subjects for the study, bone development was retarded but no other abnormalities could be demonstrated. Twenty normal children from the same socio-economic group, with ages varying between I and 5 years, were studied for comparison.

\section{Procedure}

The method used for the determination of the serum NEA:EA ratio was essentially the paper chromatographic method of Ittyerah, Pereira \& Dumm (1965), but with a slight modification. This consisted in cutting out the lysine spot and adding it to the other essential amino acids which separate above the proline spot. The NEA:EA ratio was calculated according to Ittyerah et al. (1965). Total serum proteins were estimated by the method of Wootton (1964). Concentrations of serum albumin and $\gamma$-globulin were determined by agar electrophoresis (Giri, 1956). Total serum cholesterol was determined by the method of Abell, Levy, Brodie \& Kendall (1952). Fasting blood required for the analysis was taken by venepuncture.

\section{RESULTS AND DISCUSSION}

The body-weights and heights of the children, together with the norms of Indian children, are shown in Figs. I and 2. The norms are for height and weight for age. Values for serum albumin and total protein and NEA:EA ratios are given in Table 1 . Values for healthy children of the same socio-economic group are included for comparison. The relationship between serum albumin level and NEA:EA ratio of the children is shown in Fig. 3. In Fig. 4 is shown the relationship of the NEA:EA ratio to the weight deficit of the twenty-six children studied.

The body-weights and heights of the majority of the children were approximately $75-85 \%$ of the values for normal Indian children. In a few children, the body-weight was slightly above normal owing to mild oedema. The children did not present sufficient obvious signs or symptoms to be considered ill, but their suboptimal status was objectively revealed by retarded growth and development. This retardation must have been the result of inadequate supplementary feeding.

The serum albumin concentrations were only slightly lower than normal. There was a significant $(P<0.05)$ negative correlation $(r=-0.45)$ between serum albumin and NEA:EA ratio of the children. The decrease in serum albumin concentration is much less marked in marasmus than in kwashiorkor.

The serum NEA:EA ratio in the pre-kwashiorkor children varied from 2.5 to 4.0 ; by comparison, the ratio in healthy children of the same socio-economic group varied from $I \cdot 5$ to $2 \cdot I$ with a mean of $I \cdot 7$. The results show that the NEA:EA ratio may be useful as an index for detection of a pre-kwashiorkor condition. The values reported by us vary to a certain extent from those reported by others as the method adopted by us was slightly different. The modification introduced has made it possible to determine the ratio between non-essential amino acids which separate below proline and the essential amino acids, lysine, methionine, valine, leucine, isoleucine, phenylalanine and tryptophan. The method described here gave ratios slightly higher than 
those obtained by the method of Whitehead (1964). There was lack of correlation between the ratio and weight deficit (cf. Fig. 4) in our study for all values of the ratio, including those between $2 \cdot I$ and $4^{\circ}$, which are regarded by Whitehead \& Dean (1964) as being closely related with weight deficit and of special help in the diagnosis of kwashiorkor.

Other findings in the present study are the increase in serum $\gamma$-globulin fraction

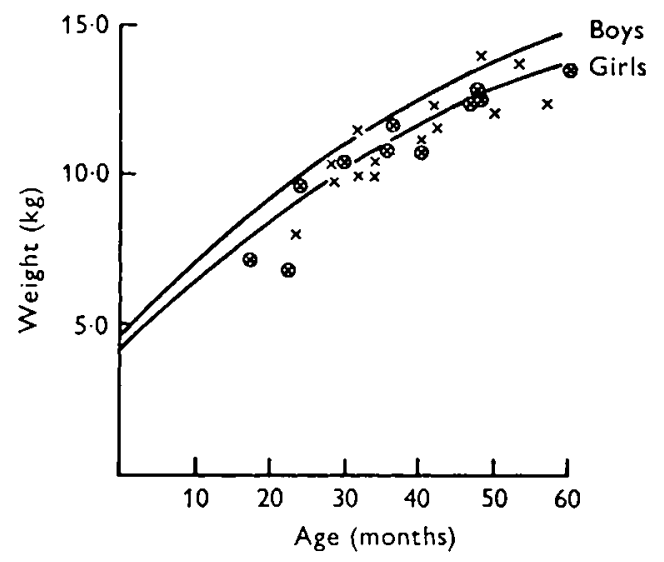

Fig. I

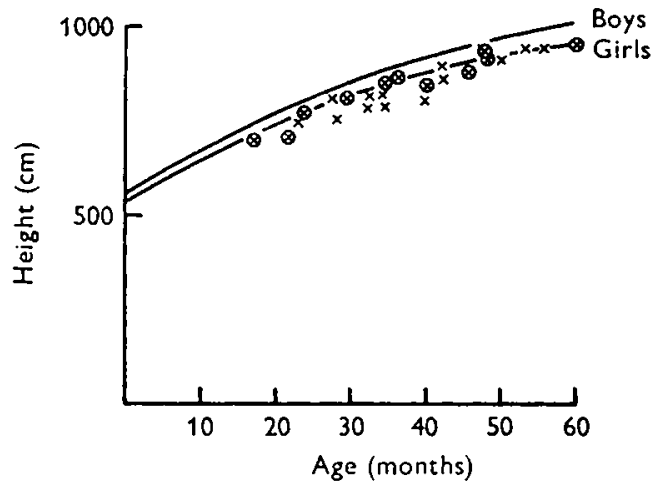

Fig. 2

Fig. 1. Body-weight of children suffering from early protein-calorie malnutrition compared with that of normal children. $x$, boys; $\otimes$, girls.

Fig. 2. Body height of children suffering from early protein-calorie malnutrition compared with that of normal children. $\times$, boys; $\otimes$, girls.

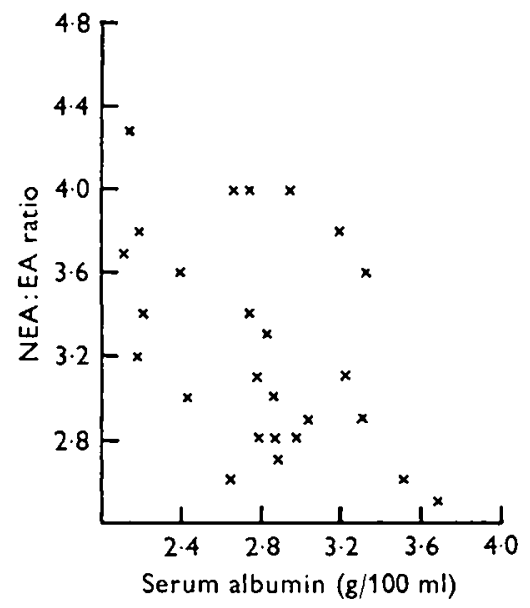

Fig. 3

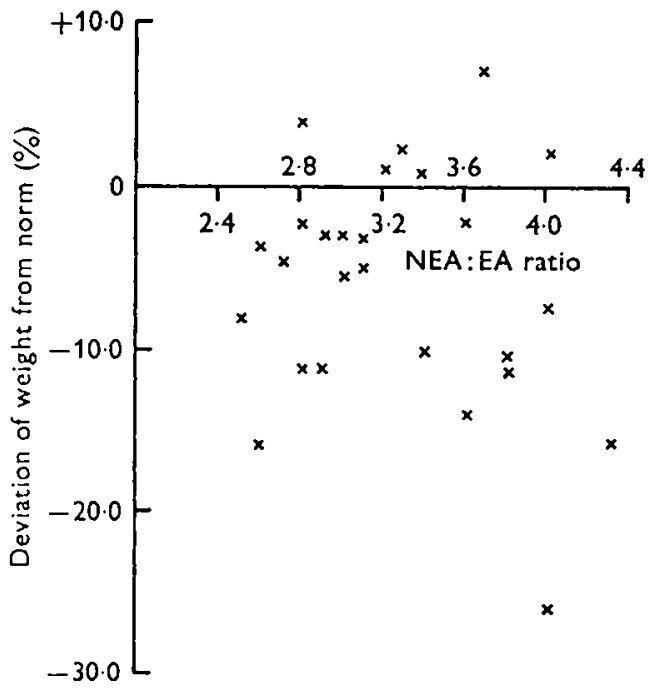

Fig. 4

Fig. 3. Relationship between the serum ratio of non-essential to essential amino acids (NEA : EA ratio) and serum albumin concentration in children suffering from early protein-calorie malnutrition.

Fig. 4. Relationship between the serum ratio of non-essential to essential amino acids (NEA : EA ratio) and weight deficit in children suffering from early protein-calorie malnutrition. 
and the slight decrease in serum cholesterol concentration in the pre-kwashiorkor children. The mean serum $\gamma$-globulin and cholesterol concentrations in the prekwashiorkor children were $\mathrm{r} \cdot 78 \mathrm{~g} / \mathrm{100} \mathrm{ml}$ and $99 \cdot 0 \mathrm{mg} / 100 \mathrm{ml}$ respectively, as compared to $1.33 \mathrm{~g} / 100 \mathrm{ml}$ and $105.0 \mathrm{mg} / 100 \mathrm{ml}$ observed in the control children.

Table I. Age, height and weight, and serum total protein concentration and non-essential to essential amino acid (NEA:EA) ratio of children suffering from early protein-calorie malnutrition

\begin{tabular}{|c|c|c|c|c|c|c|c|c|}
\hline $\begin{array}{c}\text { Child } \\
\text { no. }\end{array}$ & $\begin{array}{c}\text { Age } \\
\text { (months) }\end{array}$ & Sex & $\begin{array}{c}\text { Height } \\
(\mathrm{cm})\end{array}$ & $\begin{array}{l}\text { Weight } \\
\text { (kg) }\end{array}$ & $\begin{array}{c}\text { Weight } \\
\text { deficit } \\
\text { (kg) }\end{array}$ & $\begin{array}{c}\text { Serum } \\
\text { total } \\
\text { protein } \\
(\mathrm{g} / \mathrm{roo} \mathrm{ml})\end{array}$ & $\begin{array}{c}\text { Serum } \\
\text { albumin } \\
(\mathrm{g} / 100 \mathrm{ml})\end{array}$ & $\begin{array}{c}\text { NEA:EA } \\
\text { ratio }\end{array}$ \\
\hline $\mathbf{I}$ & I 7 & 우 & $70 \cdot 2$ & $7 \cdot I$ & 0.9 & 6.62 & 3.15 & 3.8 \\
\hline 2 & 22 & 우 & $71 \cdot 6$ & 6.7 & $2 \cdot 3$ & $6 \cdot 75$ & $2 \cdot 71$ & 4.0 \\
\hline 3 & 24 & 우 & $78 \cdot 2$ & $9 \cdot 5$ & - & 6.90 & $2 \cdot 16$ & 3.2 \\
\hline 4 & 28 & 0 & 76.5 & $9 \cdot 6$ & $1 \cdot 2$ & $6 \cdot 96$ & $2 \cdot 83$ & $2 \cdot 8$ \\
\hline 5 & 32 & 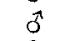 & $80 \cdot 4$ & 10.0 & $I \cdot 2$ & 5.89 & 2.30 & 3.4 \\
\hline 6 & 35 & $\stackrel{\varphi}{q}$ & $86 \cdot 2$ & 10.7 & 0.3 & $6 \cdot 54$ & $2 \cdot 75$ & $3^{I} \mathrm{I}$ \\
\hline 7 & 40 & $0^{x}$ & $8 \mathrm{I} \cdot 8$ & 10.8 & $1 \cdot 7$ & 7.10 & $3 \cdot 27$ & 3.6 \\
\hline 8 & 42 & $\partial^{x}$ & 87.0 & II 5 & $I \cdot 3$ & $6 \cdot I_{5}$ & $2 \cdot 18$ & $3 \cdot 8$ \\
\hline 9 & 50 & $\hat{\jmath}$ & $92 \cdot 0$ & II 8 & $2 \cdot 2$ & $6 \cdot 10$ & $2 \cdot 14$ & 43 \\
\hline IO & 48 & $\delta$ & $92 \cdot 6$ & 14.0 & - & $5.9 \mathrm{I}$ & 2.09 & 3.7 \\
\hline I I & 46 & 우 & 88.4 & 12.3 & 0.3 & $6 \cdot 38$ & 2.94 & $2 \cdot 8$ \\
\hline 12 & $\begin{array}{l}40 \\
56\end{array}$ & ${ }_{0}^{+}$ & 94.6 & $12 \cdot 2$ & $2 \cdot 3$ & $6 \cdot 33$ & $\begin{array}{l}94 \\
2.51\end{array}$ & $2 \cdot 6$ \\
\hline 13 & 60 & Q & 96.0 & I 3.5 & 0.3 & 6.08 & $2 \cdot 38$ & 3.6 \\
\hline 14 & 34 & $\hat{\sigma}$ & 82.0 & 10. 4 & 0.6 & $5 \cdot 82$ & $2 \cdot 41$ & 3.0 \\
\hline 15 & $3^{2}$ & $\delta$ & $82 \cdot 0$ & II 3 & - & 6.00 & $2 \cdot 80$ & $3 \cdot 3$ \\
\hline 16 & 28 & $\tilde{\sigma}$ & $82 \cdot 8$ & 10.2 & 0.3 & $6 \cdot \mathrm{II}$ & 2.96 & $2 \cdot 9$ \\
\hline I 7 & $3^{6}$ & 우 & 87.5 & II 7 & - & 6.71 & $2 \cdot 76$ & $2 \cdot 8$ \\
\hline 18 & 42 & $d$ & 90.0 & $12 \cdot 2$ & 0.6 & 7.00 & $2 \cdot 85$ & $2 \cdot 7$ \\
\hline 19 & 48 & 우 & 93.4 & 12.5 & $\mathbf{I} \cdot \mathbf{I}$ & 5.90 & 3.62 & $2 \cdot 5$ \\
\hline 20 & 29 & $\vec{\phi}$ & 82.4 & 10.2 & - & $6 \cdot 57$ & $2 \cdot 64$ & 4.0 \\
\hline 21 & $3^{6}$ & $\tilde{\sigma}$ & 86.0 & II 4 & 0.6 & $6 \cdot 48$ & $3 \cdot 18$ & $3 \cdot I$ \\
\hline 22 & 48 & 움 & $93 \cdot 3$ & 12.8 & - & 5.70 & 2.71 & 3.4 \\
\hline 23 & 53 & $\hat{\delta}$ & $95^{\cdot 2}$ & 13.6 & 0.4 & 5.52 & $2 \cdot 8_{3}$ & 3.0 \\
\hline 24 & 34 & $\partial$ & 79.0 & 10.0 & 0.8 & 6.04 & 2.92 & $4^{\circ} 0$ \\
\hline 25 & 23 & $\delta$ & $74^{\circ} \mathrm{O}$ & $8 \cdot 0$ & $I^{\circ} \mathrm{O}$ & $6 \cdot 88$ & $3 \cdot 25$ & $2 \cdot 9$ \\
\hline 26 & 40 & 우 & 84.2 & $I I \cdot I$ & 0.4 & 6.91 & 3.46 & $2 \cdot 6$ \\
\hline Valu & $s$ for healt & chil & ren of th & same soci & $\begin{array}{c}\text { onomic } \\
\text { Range } \\
\text { Mean }\end{array}$ & $\begin{array}{l}\text { up: } \\
6 \cdot 8-7 \cdot 1 \\
6.95\end{array}$ & $\begin{array}{c}3.7-3.9 \\
3 \cdot 77\end{array}$ & $\begin{array}{c}\mathbf{I} \cdot 5-2 \cdot \mathbf{I} \\
\mathbf{I} \cdot 7\end{array}$ \\
\hline
\end{tabular}

This study was supported by grants-in-aid from the PL 480 Funds, US Public Health Service. Our thanks are due to Dr H. A. B. Parpia, Director of this Institute, for his keen interest in this work.

\section{REFERENCES}

Anasuya, A. \& Narasinga Rao, B. S. (1968). Am. F. clin. Nutr. 21, 723.

Abell, L. L., Levy, B. B., Brodie, B. B. \& Kendall, F. E. (1952). F. biol. Chem. 195, 357.

Giri, K. V. (1956). F. Indian Inst. Sci. 38 A, 190.

Ittyerah, T. R., Pereira, S. M. \& Dumm, H. E. (1965). Am. F. clin. Nutr. 17, I I.

McLaren, D. S., Kamel, W. W. \& Ayyoub, N. (1965). Am. F. clin. Nutr. 17, I52.

Truswell, A. S., Wannenburg, P., Wittmann, W. \& Hansen, J. D. (I966). Lancet i, I 62.

Whitehead, R. G. (I964). Lancet i, 250.

Whitehead, R. G. \& Dean, R. F. A. (1964). Am. F. clin. Nutr. 14, 320.

Wootton, I. D. P. (1964). Micro-analysis in Medical Biochemistry 4 th ed. London: J. \& A. Churchill. 